\title{
Improving English Soft Skills Through Integrated Task-Based Learning Methods in Vocational High Schools
}

\author{
Atris Yuliarti Mulyani ${ }^{1}$, Arvina Sholawati2 ${ }^{*}$, Difa Pratama ${ }^{3}$, Halimatussa'diyah ${ }^{4}$ \\ 1,2,3,4 Teknologi Pendidikan, Fakultas Ilmu Pendidikan, Universitas Negeri Semarang, Semarang, \\ Indonesia \\ Email: ${ }^{1}$ atrisyuliarti@ students.unnes.ac.id, ${ }^{2}$ arvinasholawati@ students.unnes.ac.id, \\ ${ }^{3}$ difapratama@students.unnes.ac.id, ${ }^{4}$ diyaah620@students.unnes.ac.id
}

\begin{tabular}{r} 
Informasi Artikel \\
\hline Diterima $: 05-12-2021$ \\
Revisi $: 16-12-2021$ \\
Diterbitkan $: 20-01-2022$ \\
Keywords: \\
\hline Learning English \\
Task-Based Learning \\
Improving Soft Skills
\end{tabular}

\begin{abstract}
This study aims to find out about improving English language skills through the Integrated Task Based Learning method for vocational students. Based on the research objectives, the method in this study uses qualitative research methods with a literature review approach. The stages of the research carried out were the collection of articles and journals, reduction and summary of articles, discussion, and conclusions. Sources of research data are articles and related journals that have the same topic. The results of the study indicate that the ability to speak English is very important to be learned and mastered by vocational students. Improving their ability to speak English can be done through the ITBL method because it is very useful to prepare them to enter the world of work.
\end{abstract}

\section{INTRODUCTION}

Based on the will of the President of the Republic of Indonesia to increase the role and function of vocational high school in advancing and equitable development of socio-economic welfare in Indonesia. Conceptually and pragmatically the learning curriculum at vocational high school is designed and developed with a competency-based learning approach and a production-based learning approach. Competency-based learning applied at vocational high school is intended to reinforce with measurable mastery of competencies to students covering aspects of attitudes, knowledge, skills, and values completely and intact.[1] Meanwhile, production-based learning is intended to emphasize the achievement of competencies that must be mastered by vocational high school students and an emphasis on providing a more meaningful learning experience through actual work processes and producing goods or services by market standards by prioritizing the preparation of students for entering the workforce and develop a worthy professional attitude.

In line with the emergence of a paradigm shift towards the institutional functions and resources of vocational secondary education, which is marked by changes in the views and behavior of actors and stakeholders, English as one of the adaptive skills training subjects tends to be adaptive. "added value" for students. Linguistic Competence It is an integral part of its function as a communication language between global sectors in the company. The ability to adapt to the world of work which is inserted with an adequate structure of English competence as a medium of communication ensures that vocational high school graduates have complete strength and a high level of confidence to work together in entering the business and industrial world. Through the development of Integrated Task-Based Learning learning, this discussion is directed at developing the quality of management of Vocational High School English learning by providing opportunities for all program components, especially students \& "teachers" to play an active role in the process of managing the vocational education instructional field in an integrated \& synergized manner, starting from the planning stage, implementation stage, and evaluation stage. [1]

Therefore, it is very reasonable that some principles of learning English in vocational schools should be designed to be optimized to improve students' adaptability so that they can perform well through fluency of specific skills. 1) Starting from learning with an integrated approach to acquiring language skills; 2) Management of open and active language learning (participative and acting out); and 
3) There is an effort to improve student performance in mastering vocational high school English, as one of the prerequisites for the successful completion of vocational training programs that are by the needs of the business world, industry, and society in general. For this reason, integrated task-based learning is considered to have a high level of relevance and flexibility are quite high, when combined with aspects of the objectives of the vocational education program, the need for adaptive competence, and operational needs because of their "acting out" nature. This allows it to be used as an alternative solution in managing English learning in vocational high schools.[2]

\section{METHODS}

This scientific work is the result of literature on Improving English Soft Skills Through Integrated TaskBased Learning Methods in Vocational High Schools. the specific purpose of this scientific work is vocational high school students because it is based on the following reasons: (1) integrated based learning is appropriate to be applied in vocational high schools, (2) the use of English in vocational high schools is very influential for the world of work later; (3) many benefits will be obtained from the application of the integrated-based learning method. The literature review process is carried out by looking for references from scientific journals. All information and data collected were analyzed qualitatively and presented descriptively, namely by explaining and describing the topics studied using symbol theory and social action theory.

\section{RESULT AND DISCUSSIONS}

\section{The Need for Integrated English Learning}

In general, English is still taught in the context of a foreign language in vocational high school, it is almost too common. Therefore, the reality which is in keeping with the subject of this article, namely English in vocational high school, shows that the performance of existing vocational high school graduates cannot optimally use English as a disposition in the world of work. There are several indicators related to this:

a. Graduates do not understand how to read manuals on how to use certain tools

b. Graduates are less able to compile work reports (oral or written) which are their duties

c. Graduates are less able to adapt to the new treasury and the new system

d. Graduates are less able to communicate their exploratory creativity performance

Various reasons are considered by vocational high school graduates who are less than optimal, including:

a. Lack of availability of English teaching materials related to basic and practical skills in the rapidly growing world of work. Therefore, teaching materials tend to be general because of academics 'limitations in selecting materials that meet students' interests and desires, and development isn't supported by a needs analysis within the field.

b. The material used in the manual is less interesting. The motivation of the students is therefore low, as they believe that the English program has nothing to do with their professional field of study, so it cannot support academic success.[3]

c. English teachers are less creative and less precise in the choice of materials and the design of the teaching materials used.

d. Lack of consideration of psychological approaches and integrated learning methods, as well as student characteristics.

Of the several problems related to suboptimal English language skills in Vocational High Schools, problems related to teaching (learning) seem to be the main problems that require serious and integrated attention and management. This learning concern has a significant and strategic influence on English proficiency. This learning role is mainly related to the creation and conditioning of English language learning in vocational schools. In the English language learning program, learning to condition is directly related to the teaching and learning process, where the mechanism and results can be observed.[4]

\section{Spesial characteristic of ESP English at Vocational High School}

Based on the description above, the understanding that can be conveyed is: English for Specific Purposes (ESP), is English for special students for special purposes, special achievement orientation and the media is also special, so to get the suitability of teaching materials, teaching and learning processes, and determining the targeted achievements, it should be understood that English for vocational high school 
Adaptive Competencies has special characteristics. This characteristic relates to the basic understanding that for vocational high school English is an instrumental language for determining the expected performance for professional adaptation skills in the world of work. Plus the average vocational high school students who are below SMA. This has implications if learning English in vocational high school does not move towards English as a standard linguistic language discipline, but towards specific applied linguistics. Specifically, it implies that English for students in vocational high school is more of a tool (instrument). As a tool, English is not a holistic goal, but a partial one, namely to communicate with a "contemporary" (you know I know) approach. This approach also contains an understanding that students in vocational high school see more of function than knowledge of English

\section{Patterns - Patterns of Teaching English}

Based on an analysis of various English textbooks in vocational high school, there are patterns of teaching materials with the following coverage:

a. Vocabulary development. Vocabulary appears to be terribly dominant in learning English in vocational high school. Refers to all or any aspects of the student' field of study, particularly fields of study concerning the names of tools, types of work, and sure standard terms to apply within the field, as an example noted by vocabulary and definitions.[5]

b. Develop short phrases. Books used in learning English in vocational high school tend to be based on the development of student communication based on short phrases. In other words, the variety of language used is word for word, which produces lingua franca phrases. For example, idiomatic expressions are almost difficult to find because of the to-the-point and inclined nature of the vocational high school language (You know, I know).

c. Development of reading texts with a simple structure. Reading texts developed for vocational English learning tend to use simple language structures, instead tend to use simple effective sentences. It can be seen that the tenses used are also not complex. For example, compound complex sentences tend to be used less.

d. Procedural language development. The language used in teaching materials tends to lead to simple language with simple sentences, and tends to stories or scripts that contain procedures for working on something or mechanical manual orders.

e. Development of reading texts with a simple structure. Reading texts developed for learning English in vocational high schools tend to use language structures with a simple level, instead tend to use simple sentences. It can be seen that the form of the verb used is also not complicated. For example, compound sentences tend to be at a simple level or easy level and are usually rarely used.

Based on the characteristics of the level of English proficiency, for an implementation of English learning, the benchmark in the form of the basic principles of language learning is not something that must be standardized. However, if you want to realize the form of learning English in accordance with the correct procedure, of course the learning benchmark is an urgent need and must be met. Learning English can't be separated from the signs that are the basis for reference. The role and function of language learning reference patterns are not only as markers, but also support the foundation for further learning development. Therefore, it can be said that the reference for learning English is the embodiment of the basic principles of learning that are selected and used as a reference. In connection with this learning, there are several factors behind the implementation of English language learning also provide the possibility that English language learning in accordance with the majors in an institution will be different from other institutions.

\section{Reasons for Choosing Integrated Task-Based Learning}

Integrated task-based learning is a method of learning English that is focused on providing a series of exercises or activities aimed at achieving greater abilities. This series of exercises is usually done according to levels, ranging from easy, medium, and difficult. The levels are adjusted according to the level of difficulty. Practice that is done continuously, will create parts that will later help a broader understanding of the concepts being studied. Integrated task-based learning is considered a more comprehensive method than other methods such as the communicative method which has been considered the most appropriate in language learning. The communicative method has been more popular and applied in many languages learning options almost all over the world, this is because the existing thinking 
is based that language learning should not only be sourced from teaching language components separately, but rather towards understanding that language should be taught also as a means of learning communication. [6]

At the Vocational High School level, which requires English to be used in looking for work, of course, requires a method that is definite, effective, and easy to understand. The method is an integrated taskbased learning method. Through the development of learning using Integrated Task-Based Learning, the discussions were directed at developing the quality of management of Vocational English learning by providing opportunities for all parties involved, such as students and educators to play an active role in the process of managing the field of vocational education services in an integrated and integrated manner. synergize, starting with the initial stage of planning, followed by the implementation stage, and the evaluation stage. Integrated Task-Based Learning can accommodate the identity of students as individuals who have the potential to become creative students and perform well in a class.

Learning English in the classroom must be able to develop students' knowledge and skills in using languages, such as when carrying out communication activities that involve listening or listening skills, speaking or speaking skills, reading or reading skills, and writing skills. The four skills must be developed in a class, the integrated task-based learning method is one method that can be used to achieve these abilities. This learning is focused on using the language to be taught, and students are encouraged to carry out meaningful assignments using the language learned as a complementary instrument. Students are asked to do something specific, namely assignments in class that are by the activities they will be doing in their daily lives. Students can make the language in the classroom meaningful and memorable. Students can process the language being studied or recycled within themselves more naturally without being made up. The assignments are answered using their own opinion in English to create opportunities for them to learn the language naturally and reflectively.[7]

\section{Benefits of Integrated Task-Based Learning in the World of Work}

In today's world of work, English is one of the mandatory requirements for getting a job. By using a good English learning method, the learning outcomes given will be good too. For some graduates who use the integrated task-based learning method, in understanding English, there will be many benefits. Especially for Vocational High School graduates, the first benefit obtained is that it makes it easier for graduates to carry out their professions in the world of work, because of the possibility of understanding between fields of study that have been studied. In the world of work, there will be a lot of theory as well as practice that is needed in carrying it out, it is by this learning method. Vocational High School students who are used to carrying out practice as well as theory in each lesson, so that later they can be helped in carrying out activities in the world of work. The second benefit, because of the habits embedded in integrated task-based learning, namely the habit of communicating, in the world of work it will be easier to work in a team. [8] Good communication between members will produce maximum work results, problems at work caused by miscommunication can be overcome or prevented. The third benefit, in the use of English itself, for Vocational High School graduates who can use English effectively, in the world of work using English it will be easier to implement. Job opportunities for graduates who can use English are also very broad.

Through Integrated Task-Based Learning, providing experience in achieving competence in what is taught and also providing experience through this method. In addition, students are also accustomed to entering the workforce and developing professional attitudes that are worthy of competition. For most of the graduates of vocational schools, the ability to speak English is one of the most decisive abilities in obtaining employment. This is by the fact that English is the language of global interaction without boundaries. English is used in the development of science and technology. Mastery of English is also an important requirement to enter the world of work.[9]

In addition, the English language skills produced through the Integrated Task-Based Learning method also produce many benefits, one of which was mentioned by one of the figures, in his opinion "Improving English language skills, both spoken and written, is important to attract foreign investment, multinational companies and create high-paying jobs that are the vision of the Indonesian government for the future through business investment with better service levels," said Steve Crooks, Director of Education Research and Development at EF English First Global [10]. In addition, when English language skills are inadequate, high-paying service job offers offered by multinational companies often move to countries with a multilingual workforce. To avoid these losses, a workplace will have a standard workforce that can master two or more languages. High English proficiency is also correlated with ease of doing business. With the ability to speak English, we can attract consumers from outside so that the business that we run 
is progressing. In addition, English can also build business cooperation between one country and another[11].

\section{SUMMARY}

English is an international language that is very important to be taught and mastered by vocational high school students. Proficiency in English is an important thing to have and develop to prepare vocational high school students to enter the world of work. Through the development of Integrated Task Based Learning, vocational high school students are directed to develop the quality of English language learning management in Vocational High Schools by providing opportunities for all program components. The Integrated Task Based Learning method is an English learning method that focuses on providing a series of exercises or activities with the aim of achieving abilities that are adjusted to levels

English is one of the mandatory requirements in getting a job at this time. By applying the ITBL method to vocational high school students, it can make it easier for them to carry out their profession when they work, making it easier for them to communicate because it has been embedded in the Integrated Task Based Learning method. By improving the ability to speak English, it can attract foreign investment, offer international jobs, make it easier to do business and can attract consumers and business cooperation with other countries.

\section{REFERENCES}

[1] Y. G. S. Yuliana, "Integrated Task-Based Learning: Sebuah Alternatif Teknik Peningkatan Kompetensi Bahasa Inggris pada SMK Permesinan,” vol. 1, no. 1, pp. 22-29, 2016.

[2] A. Sekretari and B. Luhur, "SEKRETARIS DAN ADMINISTRASI PERKANTORAN Rizky Eka Prasetya ANALYSIS OF ENGLISH LEARNING NEEDS IN SECRETARY AND OFFICE ADMINISTRATION 19 . Penerapannya dapat ditemui dalam segala aspek pedagogi pendidikan tinggi . Pembelajaran jarak tinggi vokasi . Beberap,” vol. 19, no. April, 2021.

[3] H. L. Ristia Wahyuningsih, Hanifah Aulia Kusuma, "Analisis Persepsi Mahasiswa Non Bahasa Inggris Terhadap Kebutuhan Bahasa Inggris Di Dunia Kerja," J. Kaji. Keislam. Multi-Perspektif, no. April, pp. 5-24, 2016, doi: https://doi.org/10.22515/literasi.v1i2.3718.

[4] H. Utomo, "KESIAPAN KERJA SISWA SMK N 2 YOGYAKARTA PROGRAM KEAHLIAN TEKNIK LISTRIK DALAM MENGHADAPI GLOBALISASI DUNIA KERJA,” p. 32, 2012.

[5] V. Aulia, "Kajian tentang kesiapan siswa SMKN dalam penguasaan pemahaman teks Bahasa Inggris berbasis pendidikan karakter lahan basah (Wetland) sebagai local wisdom di Kota Banjarmasin," Proceeding Semin. Nas. Lahan Basah, pp. 1094-1101, 2016.

[6] I. G. A. A. D. Susanthi, "Kendala dalam Belajar Bahasa Inggris dan Cara Mengatasinya," Linguist. Comunity Serv. J., vol. 1, no. 2, pp. 64-70, 2021, [Online]. Available: https://www.ejournal.warmadewa.ac.id.

[7] M. Zibbri, H. Awwaliah, L. Lailussoma, and M. F. Nur, "Dampak Pandemi Covid-19 Terhadap Sektor Riil: Telaah, Harapan dan Penentuan Arah Kebijakan Sustainable Development Goals (SDGs) dan Ziswaf," JES (Jurnal Ekon. Syariah), vol. 6, no. 1, p. 53, 2021, doi: 10.30736/jesa.v6i1.115.

[8] S. Kurnia, "PENERAPAN METODE GRAMMAR TRANSLATION UNTUK MENGEMBANGKAN KEMAMPUAN TATA BAHASA INGGRIS SISWA SMK SARASWATI," vol. I, no. November, 2017, doi: 10.33061/awpm.v1i1.1939.

[9] A. T. Turistiati and H. F. A. Ramadhan, "Pelatihan Soft Skills Dan Pendampingan Siswa-Siswi SMK Di Kota Bogor Untuk Persiapan Memasuki Dunia Kerja," J. Komunitas J. Pengabdi. Kpd. Masy., vol. 1, no. 2, pp. 1-8, 2019, doi: 10.31334/jks.v2i1.286.

[10] C. Sutianah and U. Siliwangi, "Peningkatan kompetensi kerja berbasis integrasi soft skills, hard skills dan entrepreneur skills program keahlian kuliner melalui penerapan teaching factory smk," vol. 2, no. 08, pp. 152-167, 2021.

[11] G. Gidion, "Kecakapan Lulusan Pendidikan Tinggi Teologi Menghadapi Kebutuhan Pelayanan Gereja dan Dunia Pendidikan Kristen," Kurios, vol. 6, no. 1, p. 73, 2020, doi: 10.30995/kur.v6i1.144. 